\title{
Web of Environment and Trading Networks Through the Circulation of Currencies in the 19th Century East Coast Sumatera
}

\author{
Saparudin Barus ${ }^{1 *}$, Singgih Tri Sulistiyono ${ }^{1}$, Yety Rochwulaningsih ${ }^{1}$, Endang Susilowati ${ }^{1}$ \\ ${ }^{1}$ Doctoral Program of History, Faculty of Humanities, Diponegoro University, Semarang, Indonesia
}

\begin{abstract}
This article seeks to address how networks of trade can help explain the changing of complex environment of the commercial centres which mainly relied on ports. East Coast Sumatera, as a coastal area had hosted the power dynamics and contestations between capitalists during the colonial times. In addition to that, East Coast Sumatera was also regarded as a vital sea lane for commercial vessels and, hence, emerged into urban trading centres. This article employs historiography as the research method. Data presented in this article comprises of primary data, such as coin collections that were accessed from The Sumatran Numismatic Museum, as well as secondary data including published books and scholarly articles. This research shows that currencies found in East Coast Sumatra has demonstrated that currency was situated as the highest authority, meaning that it was not only understood as a tool of exchange in economy and monetary sense but also a tool for political legitimacy (money power) for territorial expansion, in competition for wealth. Aside from that, the produced space of maritime culture represented an environment and networks of trade that produced power.
\end{abstract}

\section{Introduction}

The emergence and development of commercial centres through ports in East Coast Sumatra rested on the control over sea routes for international trade. The control over trade routes in a certain area symbolizes economic power and diplomatic relations between regions of interest. East Coast Sumatra, a strategic area that was competed for by many parties, was shaped by the interaction between networks of traders in several regions in the East Coast Sumatra. The East Coast Sumatera had experienced ups and downs as an international trade route. The environment as a whole in the context of East Coast Sumatera in the study of history could be used to view and understand the political and economic character. In this case, this environment was the trading networks that were formed between regions in East Coast Sumatera in the 19th century.

From a certain period until the 19th century, the pattern of the international trading networks was aimed at retaining power over the monopoly of the trade of spices. These activities were done as a part of the efforts to conquer the city and commercial centres, as

* Corresponding author: s.barus1812@gmail.com 
well as the international trade routes. This process of conquering had resulted in the emergence of new commercial routes, which also triggered the emergence of new transit areas that, later, developed into new trading centres. Through inter-island networks, people had created a line of communication in certain water areas. Curtin and Poelinggomang [1] have classified two types of maritime networks: first, trade networks, which are the maritime networks formed from one area to another and tend to be outward-oriented. Second, trade diaspora, which is a network of commerce that was formed to attract wider attention to visit a certain port by offering convenience and security so that visitors became interested in fostering commercial relationships.

Traders and local communities who had interacted and communicated helped shape the international environment in the newly emerging international trading centres. The formation of the commercial environment was recognizable not only from the flow of commodities but also from the role of ports. In this sense, ports did not only function as a ship dock but also as a space for large scale trading [1]. Port also refers to its function as a shelter and haven. Besides, another term that has the closest meaning with city-centre (bandar) is port that functions as a gate or entrance. Lapian [2] argues that ports link high seas and remote inland areas in the context of maritime trade. The emergence of ports was often followed by the formation of port cities in a coastal area, which helped intensify the communications between traders. Reid [3] views ports as essential in the maritime trade in Southeast Asia, especially in affecting the traditional cruising pattern, utilizing monsoons that blow throughout the year. Ports were also the veins of economic development. For instance, the Port of Palembang, which was located in the mouth of Musi River, which is the meeting point between Musi and Bangka Straits or the Java Sea, was regarded as the veins of economic development from 1824-1864. This port was also the central circulation of currencies. Market developments in Port Palembang often became the benchmark of the trade-in entire Sumatera. As a result, in terms of the commercial centre, the Port of Palembang were often seen equal to Batavia, Gresik, Cirebon, etc. [4].

Miksic [5] mentioned that transportation and communication through open space had shaped the environmental characteristics of a distinct commercial area. East Coast Sumatera had transformed into an international trading area because of large-scale exports. Furthermore, Miksic [5] also mentioned that one region could be regarded as a tradingimperium once it possesses: commodities, ports, internal and external factors that support the growth of the imperium. The regions in Sumatera that Miksic referred to were Aceh, Barus, and Deli.

\section{Method}

This this research employs literature studies with a historiography approach. This was because currencies found in the trading networks in East Coast Sumatera needs additional history-related resources for validation. The historiographical analysis is relevant here because other than being regarded as a product of history; historiography also represents a process of writing a history [6]. The discovery of currencies in the 19th century leads us to understand the activity and trade patterns that took place in that era. All these indicate the importance of a region as a melting pot. Besides, following Gottschalk [7], this method is useful in critically analyzing the past through artefacts and archives.

\section{Result and Discussion}

Several trading centres that were situated along the East Coast Sumatera, stretching from the Province of Nanggroe Aceh Darussalam to the Province of Lampung, had experienced 
their upturns and downturns. Soon after their downturn, these trading centres were replaced by other centres, which were economically more rewarding, with a security guarantee from the rulers of the new centres. Several places in East Coast Sumatera left behind foot-steps of maritime and trading activities through the discovery of two archaeological sites: Kota Cina and Kota Rentang. Scholars, such as Milner [8], McKinnon and Sinar [9], and Ambary [10], have comprehensively studied and researched the two sites. Archaeologists have found several relics in the two sites which indicated their scale of expansion, namely fragments of Chinese ceramics, statues made of stones and metal showing a Cola style from Southern India, bricks structure believed to be a shrine, metal coins with a square hole in the middle, fragments of pottery, fragments of glass, small ornaments and the remains of the boat. All these indicate maritime activities in the Kota Cina and East Coast Sumatera in general. Besides, there was Kampai Island which was rejuvenated from the 18th-20th century. Kota Cina was an exceptionally strategic commercial centre. East Coast Sumatera was equally strategic as it became a nod of contacts and interaction from the outside world. Several regions in East Coast Sumatera had consisted of several trading centres as they were also geographically facing the Malacca Straits, which has been regarded as the main international sea route. Commercial centres in this area were also notorious for their openness, shaping the inhabitants and local communities with the character of a strong and open-minded, adopting cultural aspects that were oriented towards supporting trading activities [11].

The emergence of the trading activities cannot be separated from the interest of many, including local kingdoms and kingdoms from afar, showing an international interest in the commodities that local communities had produced. Local people at the time had been able to produce export commodities. According to Anderson, who had made an expedition to the East Coast Sumatra in 1823, locals had been trading with counterparts from Penang, a colony of the United Kingdom, in wood and plantation-based commodities. Because of this trade, British currency, including Straits Settlement coins, were found in the area. Anderson also mentioned that Penang had imported 44,180 piculs, and most were brought in from East Coast Sumatera, at least 30,000 piculs between May 1st and December 31st 1824 [12].

Archaeologists and historians also found local currencies from the international trade activities in the East Coast Sumatera. These local currencies came from local kingdoms, namely, Siak, Deli, Aceh, and Batubara. Besides, they also found foreign currencies from colonial countries such as the Netherlands, the United Kingdom, Spain, Portugal and several other trading corporations such as EIC and VOC. Currencies from countries with long and enduring friendly relations were also found, namely from India, Turkey, China, and Mexico. The involvement of various kingdoms/sultanates in the trading activities in East Coast Sumatera had indicated the intensity and interaction of trading activities in several ports in the area. The high demands for commodities such as spices had encouraged more neighbouring, or even international, kingdoms and sultanates to be involved in the trading activities. Aside from that, the circulation of such currencies also has also demonstrated a power relation in the area. Kingdoms/Sultanates in the Nusantara archipelago during that time had produced their own currencies in order to show their power and sovereignty to the trading partners.

All currencies found from the 19th century East Coast Sumatera were made of tin and copper. This type of currency was also known a 'cash, caxa, and kasya'. The circulation of this type of currency became lesser and was no longer in use as soon as the Netherlands introduced 'doit', especially when the latter currency was finally used in the payment system of international trade. The British colonial government responded to this by launching its own currency, "Singapore Merchant Token", that resembled the Netherlands 'doit'. Yet, in the token, the names of several nations were printed in the token. This printing was aimed for better reception in wider communities for the currency. The 
presence of Portugal, Spain, the Netherlands, and the British had a strong influence on the circulation of various currencies in Sumatera in the 18th century. They had also helped circulate silver currency known as "Riyal" (often referred to as "Real" and "Ringgit"). Nevertheless, there were two small currencies circulated in the area, one which was issued by a kingdom known as Pitis. The other one was a currency whose value was pegged to 'Spain Riyal' so that they are equal to 1 dirham.

\section{Conclusion}

Environment plays an important part as a social and cultural unity that affects the characteristics of the society residing in a particular region. The openness of the society and the political system had influenced the relationship and trading activities at both local and international levels. Trading activities in the region also shows the pattern of interaction and transaction in the exchange of commodities. Commodities were particularly from wood and plantations. Trading interaction has become continuous following the supply and demands of the traders in their origin countries. These trading activities would be highly reliant on the use of currencies. From the case above, it was clear that currency did not only play as a tool for exchange but also as a tool of both power politics and legitimacy (money power). Environment plays an important part as a social and cultural unity that affects the characteristics of the society residing in a particular region. The openness of the society and the political system had influenced the relationship and trading activities at both local and international levels. Trading activities in the region also shows the pattern of interaction and transaction in the exchange of commodities. Commodities were particularly from wood and plantations. Trading interaction has become continuous following the supply and demands of the traders in their origin countries. These trading activities would be highly reliant on the use of currencies. From the case above, it was clear that currency did not only play as a tool for exchange but also as a tool of both power politics and legitimacy (money power).

\section{References}

1. A. R. Hamid, Sejarah Maritim Indonesia, (Penerbit Ombak, 2013)

2. A. B. Lapian, Pelayaran dan perniagaan Nusantara abad ke-16 dan 17, Komunitas Bambu, (2008)

3. A. Reid, A Saucer Model of Southeast Asian Identity. Asian Journal of Social Science, 27(1), 7-23 (1999)

4. S. Supriyanto, Pelayaran dan Perdagangan di Pelabuhan Palembang : 1824- 1864, (Ombak Yogyakarta, 2013)

5. J. N. Miksic, Traditional Sumatran Trade, Bull. LÉcole Fr. Extrême-orient, 423-467 (1985)

6. F. Rahman, Menimbang Sejarah sebagai Landasan Kajian Ilmiah; Sebuah Wacana Pemikiran dalam Metode Ilmiah, EL-BANAT J. Pemikir. Dan Pendidik. Islam, 7(1), 128-150 (2017)

7. L. Gottschalk, Mengerti Sejarah: Terjemahan oleh Nugroho Notosusanto, Jkt. Yayasan Penerbit Univ. Indones., (1985)

8. A. C. Milner, E. E. McKinnon, T. L. Sinar, A note on Aru and Kota Cina, Indonesia, 26, 1-42 (1978) 
9. E. E. McKinnon, T. L. Sinar, A Note on Pulau Kompei in Aru Bay, Northeastern Sumatra, Indonesia, 32, 49-73 (1981)

10. H. M. Ambary, Further Notes on Classification of Ceramics from the Excavation of Kota Cina, Stud. Ceram., 63-72 (1984)

11. H. M. Ambary, Peranan Beberapa Bandar Utama di Sumatra Abad ke-7-16 M dalam Jalur Perdagangan Internasional, in Proceedings Internasional Symposium for Japanese Ceramics of Archaeological Sites in South-East Asia: The Maritim Relationship on 17th Century, Pusat Arkeologi dan The Japan Foundation Jakarta, 12$23(2000)$

12. J. Anderson, Mission to the East Coast of Sumatra, in 1823, William Hackwood (1826) 